\title{
Perception of Local People Towards Tannery Industrial Waste: A Cross-Sectional Study on Hazaribagh Areas of Dhaka City
}

\author{
Amzad Hossain ${ }^{1}$, Serajum Munira ${ }^{2,3} \&$ Meherun Nessa ${ }^{4}$ \\ ${ }^{1}$ Department of Sociology, Government Edward College, National University, Bangladesh \\ ${ }^{2}$ Liton Baron Sikder, Assistant Professor, Department of English, Islamic University, Kushtia, Bangladesh \\ ${ }^{3}$ Department of English, Green University of Bangladesh, Bangladesh \\ ${ }^{4}$ Department of Language (English), Shere-e-Bangla Agricultural University, Dhaka, Bangladesh \\ Correspondence: Md. Amzad Hossain, Lecturer, Department of Sociology, Government Edward College, \\ National University, Pabna, Bangladesh.
}

Received: March 23, 2021

doi:10.20849/ajsss.v6i4.950
Accepted: April 30, 2021

Online Published: November 18, 2021

URL: https://doi.org/10.20849/ajsss.v6i4.950

\begin{abstract}
Though tannery industries such as RMG and pharmaceuticals have played a significant part in the country's economic sectors, they have had a serious detrimental impact on tannery workers and the Dhaka metropolitan environment. The major objective of the study was to measure the association between socio-demographic factors and perceptions of local people towards tannery industrial wastes. Following a simple random sampling technique, this study chose 384 respondents from the study area. The findings of the study reveal that a whopping $95 \%$ of respondents reported that tannery industrial wastes have serious effects on the environment in the study area. Again, the bivariate result of the study indicates that male, married respondents, educated respondents, and respondents with higher income are more likely to say that tannery waste is harmful to local people while male \& age of the respondents, marital status, Muslim religion, and higher-income group socio-demographic variables are significantly associated with tannery industrial waste handling is highly risky. Moreover, sex, marital status, religion, and higher-income group are also found as significant indicators for creating disease by tannery industrial waste as well as sex, age and income have been found as the predictor for Tannery industrial waste segregation are essential.In conclusion, this study mainly emphasizes tannery industrial waste on the workers' health problems and lifestyles, furthermore, the findings also showed the environmental awareness \& perceptions of local people caused by the hazardous tannery waste.
\end{abstract}

Keywords: tannery waste, health hazards, workers health risk, environment pollution, common disease

\section{Background of the Study}

By dumping liquid effluents and solid wastes directly into low-lying areas without sufficient treatment, the leather industry poses a serious environmental concern. Industrial wastes are major polluters in all settings and must be treated on-site before being discharged into the sewer system (Emongor et al., 2005). Hazaribagh is the lifeline of Dhaka city, as shown on the map, where the tanning industry began in 1960 . Waste is generated by all sections of society, including agriculture, industry, mining, construction, consumers, energy, and transportation. Because different industrial processes generate different types of waste, the quantity of toxicity of waste emitted from industrial operations varies from one industrial process to the next. Every day, the tanneries dump 22,000 liters of toxic waste into Buriganga, containing cancer-causing chromium, according to the Ministry of Environment (Barton, 2011).

In the future, there will be a significant number of deaths in this location, according to the expert. However, as in every developing country, the economy takes precedence over the environment. The situation is deteriorating due to a lack of improvement in the wastewater treatment and management system, as well as the formulation and effective execution of policies aimed at preserving and regenerating the environment, as well as insufficient sewerage and infrastructure facilities (Banani Bisws and Takeshi Hamada) (2012).

The leather industry contributes to one of the world's most serious industrial pollution problems (M.Jatavathu etl 2011). The wastewater from these industries contains a variety of harmful compounds such as lime, sodium, sulphide salts, and solvents, which are all utilized extensively in the pre-tanning stages of leather manufacturing. 
The use of traditional proteases has considerably reduced but not eliminated the need for chemical application (UNIDP, 2000).

Around $75 \%$ of the organic waste generated by a tannery comes from the beam house, and $70 \%$ of this waste is nitrogen-rich hair. This diagram clearly depicts the contribution of the lime and sulphide processes to pollution (M. Jatavathu et al, 2011).

Tannery industries are illegally dumping untreated liquid tannery wastes in Hazaribagh. Dhaka is the primary polluter of Buriganga. For 45 years, the chromium emitted by the Hazaribagh tannery businesses has contaminated the Buriganga river's water. According to figures from the Department of Environment, over the last fifty years, 95 percent of tannery enterprises have been established in an uncontrolled manner in congested areas of Hazaribagh. According to a recent estimate, these tanneries process over 60,000 tons of raw hides and skins annually, releasing over 95,000 liters of untreated effluents into the open environment on a daily basis, culminating in the death of the river Buriganga (M.K.) (Russel, I. Faisal, and Kamal, K.M.M., 2006). According to the WHO, around 8,000 workers in Hazaribagh's tanneries suffer from gastrointestinal, dermatological, and other diseases, and $90 \%$ of this group dies before reaching the age of 50. (J. Marice, 2001).

\section{Materials and Methods}

\subsection{Overview of the Study}

The best reason for the selection of this area is that people of the Hazaribagh area are the victims of various diseases for severe types of tannery Industrial wastes. Various studies and surveys are indicated that the Hazaribagh area is an important part of the capital city and facing different types of pollutions, and caused health Hazards. On the basis of data gathered from a daily newspaper, the area was selected finally. It is to be mentioned that the highest concentration was given to study this area.

\subsection{Study Area and Participants}

The study covered some areas of Hazaribagh, Dhaka cities such as Zigatoala, Rayerbazar, and Leather technology college campus. But because of some accessibility, the researcher also selected the Zafrabad Road area. There were several distinct target populations in this study. The following populations were targeted: tannery workers, a rickshaw puller, housewives, and Lather College students.

\subsection{Sampling \& Sample Size Determination}

The sampling frame was identified by following the random sampling technique within the tannery industrial area and Leather Technology College Campus of Hazaribagh, Dhaka.

$$
n=p \times q \times t^{2} / d^{2}
$$

where: $\mathrm{n}=$ the desired sample size (if the target population is greater than 10,000),

$\mathrm{t}=$ critical value for the desired confidence level (alpha),

$\mathrm{p}=$ proportion in the target population estimated to have characteristics being measured,

$\mathrm{q}=1-\mathrm{p}$, and $\mathrm{d}=$ desired precision.

Since no estimate was available for the expected proportion of the target population which had the characteristics of interest then, $50 \%(\mathrm{p}=0.5)$ was used and the confidence level was set at $95 \%$ for which $\mathrm{t}=1.96$ resulting in the sample size of 384 .

\subsection{Data Collection}

The data collection instrument was a self-administered questionnaire distributed to respondents. The surveys were written in English, and 15 samples from the research region were used to detect gaps and adjust the questionnaire. The pre-test responders were not included in the main study.

\subsection{Data Analysis}

SPSS Version 20.00 was used to conduct statistical analyses on the data. Here, Frequencies and percentages were used to present for categorical variables, and mean, variance, standard deviation were used for continuous variables.

For further analyses, the study included the bi-variate statistical analysis of difference among variables and the various risk factors were identified by the categorical variable by using multiple binary logistic regressions to evaluate the risk factors for identifying predictors' variables. All statistical tests were performed using two-sided tests with a significance threshold of 0.05 . Values less than 0.05 are recorded as 0.05 . P-values are published to three decimal places. Furthermore, p-values less than 0.05 were considered statistically significant. 


\subsection{Ethical Consideration}

An informed permission form was signed and received from the respondents in order to perform this study. The respondents' identities were kept private at all times. The respondents' identities were kept hidden to protect anonymity. Respondents were informed that participation in the study was entirely optional and that they might opt-out at any time.

\section{Result \& Discussion}

Table 1. Demographics variables

\begin{tabular}{|c|c|c|c|}
\hline Variables & Category & Frequency & Percent \\
\hline \multirow[t]{2}{*}{ Sex of the respondents } & Male & 315 & 82.0 \\
\hline & Female & 69 & 18.0 \\
\hline \multirow[t]{5}{*}{ Age of the respondents } & $15-20$ & 8 & 2.1 \\
\hline & $20-25$ & 46 & 12.0 \\
\hline & $25-30$ & 199 & 51.8 \\
\hline & $30-35$ & 100 & 26.0 \\
\hline & $35+$ & 31 & 8.1 \\
\hline \multirow[t]{3}{*}{ Marital Status } & Married & 311 & 81.0 \\
\hline & Unmarried & 72 & 18.8 \\
\hline & Widow & 1 & .3 \\
\hline \multirow[t]{2}{*}{ Religion of the respondents } & Muslim & 323 & 84.1 \\
\hline & Hindu & 61 & 15.9 \\
\hline \multirow[t]{5}{*}{ Education of the respondents } & No Education & 121 & 31.5 \\
\hline & Can Sign Only & 106 & 27.6 \\
\hline & Primary & 79 & 20.6 \\
\hline & S.S.C & 50 & 13.0 \\
\hline & H.S.C & 21 & 5.5 \\
\hline \multirow[t]{6}{*}{ Income of the respondents } & $>3000$ & 124 & 32.3 \\
\hline & $3000-6000$ & 110 & 28.6 \\
\hline & $6000-10000$ & 73 & 19.0 \\
\hline & $10000-15000$ & 49 & 12.8 \\
\hline & $15000-20000$ & 21 & 5.5 \\
\hline & $20000+$ & 7 & 1.8 \\
\hline
\end{tabular}


Table 2. Bivariate results of the study

\begin{tabular}{ll}
\hline Socio-demographic variables & Industrial waste harmful \\
\hline Sex & $\mathrm{V}=0.95^{* * *}$ \\
\hline Age & $\mathrm{V}=0.10$ \\
\hline Marital status & $\mathrm{V}=0.92^{* * *}$ \\
\hline Education & $\mathrm{V}=0.21 *$ \\
\hline Religion & $\mathrm{V}=0.00$ \\
\hline Occupation & $\mathrm{V}=0.10$ \\
\hline Income & $\mathrm{V}=0.79 * * *$ \\
\hline Income & $\mathrm{V}=0.79 * *$ \\
\hline *** $\mathrm{P}=0.001 ; * * \mathrm{P}=0.01 * * \mathrm{P}=0.05$ &
\end{tabular}

Table 3. Bivariate results of the study

\begin{tabular}{ll}
\hline demographic variables & Waste creates disease \\
\hline Sex & $\mathrm{V}=0.46^{* *}$ \\
\hline Age & $\mathrm{V}=0.10$ \\
\hline Marital Status & $\mathrm{V}=0.48^{* * *}$ \\
\hline Education & $\mathrm{V}=0.11$ \\
\hline Religion & $\mathrm{V}=0.16$ \\
\hline Occupation & $\mathrm{V}=0.19$ \\
\hline Income & $\mathrm{V}=0.89 * * *$ \\
\hline$* * * \mathrm{P}=0.001 ; * * \mathrm{P}=0.01 ; * \mathrm{P}=0.05$ & \\
\hline
\end{tabular}

Table 4. Bivariate results of the study

\begin{tabular}{ll}
\hline Socio-demographic variables & Tanner wastes handling risky \\
\hline Sex & $\mathrm{V}=0.94^{* * *}$ \\
\hline Age & $\mathrm{V}=0.59^{* * *}$ \\
\hline Marital & $\mathrm{V}=0.50^{* *}$ \\
Status & \\
\hline Education & $\mathrm{V}=0.17$ \\
\hline Religion & $\mathrm{V}=0.66^{* * *}$ \\
\hline Occupation & $\mathrm{V}=0.83^{* * *}$ \\
\hline Income & $\mathrm{V}=.68^{* * *}$ \\
\hline$* * * \mathrm{P}=0.001 ; * * \mathrm{P}=0.01 ; * \mathrm{P}=0.05$ & \\
\hline
\end{tabular}

\section{Discussion}

As the demographic table, the description of the sex respondent depicts that male was $82 \%$ and the remaining respondents were female. Moreover; the age of (15-20) ages were $2.1 \%$ and the other age groups were $12 \%$, $51.8 \%, 26 \%$, and $8.1 \%$.

The assessment of marital status found that the married students only were $81 \%$ and the rest numbers of the respondents were unmarried. Another demographic factor was religion in the study, as a Muslim-oriented country, most of the respondents were Muslims, the rate was $84.1 \%$ percent. The last variable of the demographic profile was the education status of the respondents.

Following a simple random sampling technique, this study chose 384 respondents from the study area. The findings of the study reveal that a whopping $95 \%$ of respondents reported that tannery industrial wastes have serious effects on the environment in the study area.

Harald Cramér (1946) recommended the following statistic, known as Cramér's V or Cramér's phi, to assess the connection between categorical variables with more than two levels: $\mathrm{C}$ is equal to the square root of $(2 / \mathrm{N}(\mathrm{L}-$ 
1)). Cramér's V is a variation of the phi coefficient that adds a denominator adjustment, where $\mathrm{L}$ is the smaller value 3 of either the number of columns or the number of rows. Because there are fewer columns than rows in a 3 $\mathrm{x} 4$ contingency table, $\mathrm{L}$ would be 3 . Cramér's V statistic, like the phi coefficient, spans from 0 to 1 , with higher values suggesting stronger correlations or impact sizes. The contingency coefficient, which alters the denominator of the phi coefficient by combining $\mathrm{N}$ with the chi-square statistic, is another similar measure of association statistic for variables with more than two levels. The contingency coefficient, unlike Cramér's V and the phi coefficient, does not have a range of 0 to 1 . Cramér's $V$ is often used for this reason, despite the fact that these statistics are related.

Because it delivers good norming from 0 to 1 regardless of table size when row marginals equal column marginals, Cramer's V is the most popular of the chi-square-based nominal association measures. $\mathrm{V}=\mathrm{SQRT}(\mathrm{X} 2 / \mathrm{nm})=\mathrm{V}=$ $\operatorname{SQRT}(\mathrm{X} 2 / \mathrm{nm})=\mathrm{V}=\mathrm{SQRT}(\mathrm{X} 2 / \mathrm{nm})=\mathrm{V}=\mathrm{SQRT}(\mathrm{X} 2 / \mathrm{nm})=\mathrm{V}=\mathrm{SQRT}(\mathrm{X} 2 / \mathrm{nm})=\mathrm{V}=\mathrm{SQRT}(\mathrm{X} 2 / \mathrm{nm})=\mathrm{V}=$ $\operatorname{SQRT}(\mathrm{X} 2 / \mathrm{nm})=\mathrm{V}=\mathrm{SQRT}(\mathrm{X} 2 / \mathrm{nm})=\mathrm{V}=\mathrm{SQRT}(\mathrm{X} 2 / \mathrm{nm})=\mathrm{V}=\mathrm{SQRT}$ Because $\mathrm{V}$ has a well-known sample distribution, its standard error and significance may be calculated. The significance level of the estimated $\mathrm{V}$ value is reported by SPSS and other major software. Liebetrau provides the formula for Cramer's V variance (1983: 15-16).

The result indicates that male, married respondents,educated respondents, and respondents with higher income are more likely to say that tannery waste is harmful to local people (Table 2 . Bivariate results of the study, $V=0.95 * * *$, $\left.\mathrm{V}=0.10, \mathrm{~V}=0.92^{* * *}, \mathrm{~V}=0.21^{*}, \mathrm{~V}=0.00, \mathrm{~V}=0.10, \mathrm{~V}=0.79^{* * *}, \mathrm{~V}=0.79^{* * *}, * * * \mathrm{P}=0.001 ; * * \mathrm{P}=0.01 * * \mathrm{P}=0.05\right)$. While male \& age of the respondents, marital status, Muslim religion, and higher-income group socio-demographic variables are significantly associated with tannery industrial waste handling is high risky, $* * * \mathrm{P}=0.001 ; * * \mathrm{P}=0.01 ; * \mathrm{P}=0.05$. Moreover, sex, marital status, religion, and higher-income group are also found as significant indicators for creating disease (Table 3 . Bivariate results of the study) by tannery industrial waste as well as sex, age and income have been found as the predictor for tannery industrial waste segregation are essential. In conclusion, this study mainly gives emphasis to tannery industrial waste on the workers' health problems and lifestyles, furthermore, the findings also showed the environmental awareness \&perceptions of local people caused by the hazardous tannery waste.

The more locally-oriented environmental hazards derive from the regular pending of large quantities of liquid and solid wastes within or directly adjacent to the Hazaribagh area. The problem is quite acute, endangering directly the human environment, but can be improved adequately by rehabilitation of the collection system and regular collection of the solid water.

The magnitude of water pollution from tannery waste has already taken considerable dimension to dimension public health in general. With the increasing hazard of pollution of surface bodies of water due to indiscriminate discharges of sewage and industrial effluents into them, there has been felt the growing necessity to study the magnitude of the pollution problems and to find out a suitable method for the prevention of such pollution.

There is no doubt about the obnoxious odor in the Hazaribagh area due to the lacking collection and disposal system of the wastes. The overflowing of the roads throughout the Hazaribagh area is a common problem during the rainy season. The odorous wastewater flows over the roads and causes a serious problem.

Tanneries release inorganic, organic, and hazardous pollutants that must be carefully treated prior to disposal to ensure that the receiving body of water is not contaminated physically or biologically. Each day, tannery waste with a high concentration of dissolved solids, suspended particles, chlorides, ammonia, and an unusually high BOD content is released into the receiving body of water at Hazaribagh (1). In any modern country, industrial waste with such a high concentration of poisons is not permitted to be disposed of organically.

The disposal of tannery wastewater in the low-lying area at Hazaribagh contributes to a high concentration of suspended solids and other volatile solids which render the water unsuitable for domestic and other purposes, the situation can be improved when this waste can be disposed into a large stream of continuously the following water. Thus thenature and amount of pollutants if discharged in the alternative large river cannot deteriorate the water quality of the receiving body of water.

The soil productivity is adversely affected when tannery waste-waters are applied on land and so in e parts of the laud may become completely infertile. This effect is primarily attributable to the presence of an excessive amount of salt in tannery waste. Inspire of the presence of high calcium, and possibly also magnesium, in the wastewater, its sodium Adsorption Ratio has been observed to be much higher than 10 in most cases, as a result of which the wastewater. Inspire of the presence of high calcium, and possibly to the soil, some of the complex organic compounds, especially things, are the other inhibitor agents present in the wastewater. 
Discharge of tannery wastewater on land adversely affects groundwater quality due to the presence of high amounts of chlorides chromium, tannins, etc. Dug wells located near some tanneries at Hazaribagh have been contaminated with the wastewaters (2).

The problem of air pollution from the Hazaribagh tannery industry has been reported to be caused by the unpleasant odor which is the characteristic of a tannery. The obnoxious odor spreads out all over the Hazarihagh area and is a part of Dhanmondi R/A during the summer when the rate of decomposition of organic matters is higher. The areas invaded by bad odors from Hazaribagh tanneries are shown in fig.

Animal skins consist of three layers, the outer layer being known as the epidermis, the intermediate layer made of fatty tissues, and the inner layer known as corium. It is the corium from which leather is made. The principal constituent of corium is the protein collagen which, when subjected to the action of tanning agents, undergoes transformation and becomes insoluble in water, tough and flexible, the processes which are carried out to bring about this transformation have been traditionally categorized under two headings, one being the beam house processing and the other tan yard processing, the former operations being intended to prepare the hides for tanning. Figures 2.1 and 2.2 depict the methods used in a tannery for vegetable tanning and chrome tanning of hides and skins, as well as wastewater sources.

From the analysis report, it appears that the discharge is strongly polluting. The Rx. D and COD results indicate toxic conditions or the presence of biologically resistant organic matters. Considering the type of enemas used ant the process the particular parameters of pollution to tanneryeffluent are shown below: a) Physicali) Solidii) Grease or oilb) Organicc) Toxic chemicals

Tannery wastewater various considerably in quantity and quality during the entire process of hiding preparation, tanning, and Finishing. It is seen from the analysis carried out by "AQUA" and "BKH" consulting engineers (2) that 60 percent of the waste flow contains about 75 percent of the total COD pollution load and nearly the total load of suspended solids.

However, at the outfall of the collection system a core or 1'ess homogeneous influent was obtained due to mixing of the wastewater, flows from the various stages in the process.

As part of the survey, the composition of the wastewater was measured at various timesduring, the study; wastewater samples were collected at points SI and S2 at several dates during the study period. Since no suitable laboratory facilities were available a number of samples were sent to the Netherlands for analysis. The results of the analyses are given in Table 2.

The average composition of the wastewater for the Hazaribagh area is given in Table 3. The table also shows the composition according to the World Health Organization (WIO) for comparable water consumption. It can be concluded from the above table that the wastewater at Hazaribagh is relatively diluted in view at the low concentrations of chromium $\left(\mathrm{Cr}^{3+}\right)$ and sulphide. However, the high concentrations of COD and solids in the Hazaribagh Wastewater indicate that a large quantity of solid waste is discharged with the wastewater. The values of specific resistance to filtration and coefficient of compressibility of mixed primary and secondary sledges were found to be $3.68 \times 10^{13} \mathrm{~m} / \mathrm{kg}$ and Q.58 respectively. A good dewater able sludge should have specific resistance less than $0.1 / 10^{13} \mathrm{~m} / \mathrm{kg}$ (2). The higher values of specific resistance and coefficient of compressibility indicate that dewatering of such sludge by any method including drainage and dryings on beds, commonly used in developing countries, would be difficult and delayed and would cause obnoxious conditions offensive to sight and smell.

The number of solid wastes of different nature and quantities is produced in a tannery. Jalt dusts are produced in handling and storing raw salted hides and skins. Wet lime sludge is produced in significant quantity in the liming process. Hairs and green fleshing are produced in Unhearing and fleshing operations. Vegetable and chrome tanned shavings are also produced after respective tanning operations. However, spent veritable tanbark and spent myrobalan nuts constitute the largest fraction of the solid wastes generated in a vegetable tannery. Among these solid wastes, the sludges from the chrome tanning operation are hazardous in nature since these sledges contain almost all the chromium which remains unutilized in the tannery.

\section{Conclusions and Recommendation}

From the salient features of the discussion, it is apparent that the tanneries are the polluters of the environment and depositors or the environmental quality. The relevant authorities have virtually no control over the timely collection and disposal of wastewater and solid wastes. From such open dumping of wastes, objectionable odors and matters spread in and around Hazaribagh. To prevent degradation of the environment shifting the tanneries from Hazaribagh to another place is strongly recommended for the following reasons: 
The shifting of tanneries outside of Dhaka will cost gigantic funds against numerous benefits. The points in favor of shifting the tanneries outside Dhaka are stated below: The tanneries at Hazaribagh are located in such a mixed area that there is no extra space for further extension. Under these circumstances, some modernized tanneries have to make their factories two-storied or three-storied. But for the tannery industry Target floor area is essential to install more machinery which cannot possibly be installed on the first and floor. But a Larger area ( 80 acres) can be acquired for industrialization outside Dhaka at Nayerhat.

In sludge drying beds injurious sulphide and chromium mixed with dry sludge spread obnoxious odors. For disposal of such dry sludge a large open space is required which is not available at Hazaribagh. Moreover, this system of sludge disposal will be inoperative in the rainy season causing the same problem.

The above sludge drying system will be available to both large and small tanneries if the tanneries are situated outside the urban area when the alkaline beam house waste and acidic tan house waste are discharged into the same open drain, odorous hydrogen sulphide gas evolves which should not be permitted in a residential area. Obnoxious odors and unhygienic dumping of solid waste which are rendering the Hazaribagh tannery area inhospitable can be reduced by shifting of the tanneries. The odor created from the rapid decomposition of organic matter invades the surrounding areas like Dhanmondi R/A and jigatola R/A. This can be avoided only by shifting tanneries.

A huge amount of water and chemicals are required forbids processing and also water is required for other domestic purposes, for the official and workers. To fulfill the requirement a significant amount of Hinds has to be invested for deep tube well installation and maintenance. If the tanneries are shifted outside Dhaka on the bank of the flowing river then the water requirement can be partly fulfilled by the river water thereby saving a major amount of money spent on water supply. At present, the public authorities such as the Dhaka Municipal Corporation, Dhaka WASA, and Dept. of Public Health Engineering are not in a position to take care of such a huge amount of wastewater and solid waste management in a hygienic manner due to lack of funds. So shifting of the tanneries to sites where wastewater can be disposed of after primary treatment is preferred. Due to the availability of land, provision for future secondary treatment of tannery wastewater is possible at Nayerhat. Of all the above-mentioned advantages, the most important one, which cannot be assessed by economic returns, is the improvement of the environmental quality of the area, due to this improvement more people will be inclined to live and work in this area and the house owner will be benefited by obtaining a higher return from their property.

\section{References}

Banani, B., \& Takeshi, H. (2012). Relation between Hazaribagh Tannery Industry Development and Buriganga River Pollution in Bangladesh. International Journal of Environment, 2(2), 117-127.

Barton. (2011). Bangladeshs deadly leather industry: A news report (online). Retrieved 8 March 2011, from http://thestar.com.mylifestyle/store.asp?file=/2011/3/8.Lifecourse/8094926 and sec=lifefo

Cramér, H. (1946). Mathematical Methods of Statistics. Princeton Press, Princeton, NJ, pp. 367-369.

Jatavathu, M., et al.. (2011, December). Efficient leather dehairing by Bacterial thermostable protease. International Journal of Bio-Science and Bio-Technology, 3(4).

Liebetrau, A. M. (1983). Measures of association. Newbury Park, CA: Sage Publications. Quantitative Applications in the Social Sciences Series No. 32.

Marice, J. (2001). Tannery pollution threatens health of halt -millions Bangladesh residents. Bulletins of the World Health.org 79.1.

Russel, M. K., Faisal, I., \& Kamal, K. M. M. (2006). Environmental pollution generated from process industries in Bangladesh. Int. J. Environment and Pollution, 28(1/2), 44-161.

United Nations Industrial Development Organization. (2000).

\section{Copyrights}

Copyright for this article is retained by the author(s), with first publication rights granted to the journal.

This is an open-access article distributed under the terms and conditions of the Creative Commons Attribution license (http://creativecommons.org/licenses/by/4.0/). 